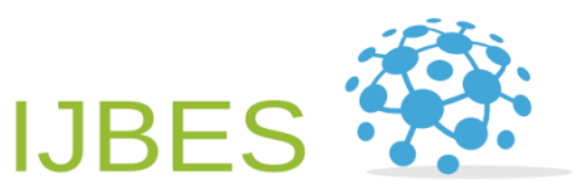

Business Ecosystem \& Strategy

IJBES VOL 2 NO 1 ISSN: 2687-2293

Available online at www.bussecon.com

\title{
E-commerce marketing strategies in industry 4.0
}

\author{
Ramdani Murdiana $a^{*}$, Zineb Hajaoui $\oplus_{b}$ \\ a,b School of Business, Ibn Haldun University, 34494, Istanbul, Turkey
}

\begin{tabular}{l} 
A R T I C L E I N F O \\
\hline Article history: \\
Received 07 October 19 \\
Received in revis. form 22 Novm. 19 \\
Accepted 08 December 19 \\
\hline Keywords: \\
E-commerce \\
Marketing strategy \\
Industry 4.0 \\
JEL Classification: \\
M30
\end{tabular}

\begin{abstract}
A B S T R A C T
The business transition process from conventional to digital forms causes companies to think about strategic steps to make the new business processes that are in it become sustainable. One way is to take advantage of technological developments in the era of industry 4.0 that change the way work is done from the conventional way towards digital technology by utilizing e-commerce. This research uses descriptive research method with a qualitative analysis approach. Data collection techniques in this study used primary data and secondary data approaches. Data obtained from research are empirical data. The methodology used in this study is a conceptual review, which is a method carried out by collecting data and information related to market potential, changes in consumer behavior and how to use e-commerce technology as an alternative solution in innovating marketing strategies with the aim to capture potential market potential. greater than. The results of the research resulted nine ecommerce strategies in the industry 4.0 era to achieve the goals of a business with challenges and high competitiveness in the e-commerce market, business people in industry 4.0 era can use 9 strategies to successful in this technological era, including; framing the market opportunity; formulating the marketing strategy; designing the customer experience; crafting the customer interface; designing the marketing program; leveraging customer information through technology; character and competent delegation; systemized market customers; and evaluating the marketing program.
\end{abstract}

\section{Introduction}

In this digital age, technological developments occur in the development of media technology, namely online media. This media is also a media which until now has not matched the growth in the number of users. In developed countries, online media capture various media that have previously taken reference sources to obtain information. The term new media emerged in the late 20 th century, this term is used to refer to a new type of media that combines conventional media with internet media.

In the past few years online media have been enlivened by the phenomenon of the emergence of social networking sites. The development of information technology that occurred led to the term e-commerce which is the process of buying and selling products, services and information that is done electronically using the internet network. Opportunities and challenges in conducting internet marketing communication make a new breakthrough in the world of product or service marketing, especially in the industry 4.0 . Interactive media allows a reciprocal flow of information that allows users to participate and modify the contents of the information at that time (real time). This interactive ability is also owned by social networking platforms such as Facebook and other social networks, this is what makes online media superior to traditional media which is only one-way in delivering communication messages.

Whereas social networking media like Facebook are able to provide direct feedback so that personal communication is created. From various online media developments in the industry 4.0, was born a platform that provides opportunities for buying and selling features amid the emergence of communication media that encourage an increase in quality in life in this era. Many platforms in online media are starting to become an opportunity for business people in the era of the industry 4.0 which is used as a business stall. Based on survey results according to the Global Internet Use Accelerates (2019) the Global E-commerce Spend by category explains that the total annual amount spent on consumer e-commerce categories around the world is \$ 524.9 billion for fashion and beauty, \$ 392.6 billion for Electronics and Physical Media, \$ 209.5 billion for food and personal care, \$ 272.5 billion for furniture and appliances, \$

* Corresponding author. ORCID ID: 0000-0001-5812-7950

(C) 2020 by the authors. Hosting by Bussecon International. Peer review under responsibility of Bussecon International Academy. http://dx.doi.org/10.36096/ijbes.v2i1.165 
750 billion for (travel (including accommodation), \$ 12.05 billion for digital music, \$ 70.56 billion for video games, \$286, 2 billion for toys, DIY (Do It Yourself) and hobbies.

Digital Market Outlook studies show that e-commerce spend has grown by 14 percent year-on-year, with the company estimating that full-year 2018 spend on consumer goods alone topped US\$1.78 trillion. Based on the survey results, business people are under pressure from the impact of this digital era which is driving e-commerce platforms to become a trend of business today. Not only social media, but the global internet marketing (e-marketing) platform such as Amazon and Alibaba has also become an intermediary that supports the existence of companies in the current digital media era.

E-marketing platform is a part of business operations that is used today as the start of product launches, developing customer loyalty and news dissemination, with these conditions the design of online business strategies in the current digital media era is certainly an opportunity for business people to do online marketing to meet various needs starting from primary needs to secondary needs. Although many business people are getting used to using technology, but have not used it optimally. Especially in matters of productivity of e-commerce advertising that can develop sales. Various strategies must be carried out to maintain existence in the competition in the industry 4.0, this becomes a new opportunity for business people. Based on the above background, the problem formulation in this research is how e-commerce strategy in the digital age.

In this study, it is to determine the e-commerce strategy in the digital age. This study used descriptive research method with qualitative analysis approach, which is research that intends to understand the phenomenon of what is experienced by research subjects. Data collection techniques in this study using primary data and secondary data approach. Data obtained from research are empirical data.

\section{Literature Review}

The term industry 4.0 was born from the idea of the fourth industrial revolution. European Parliamentary Research Service in Davies (2015) said that the industrial revolution happened four times. The first industrial revolution took place in England in 1784 where the invention of steam engines and mechanization began to replace human work. The second revolution took place at the end of the 19th century in which production machines powered by electricity were used for mass production activities. The use of computer technology for manufacturing automation starting in 1970 marked the third industrial revolution. Today, the rapid development of sensor technology, interconnection and data analysis has led to the idea of integrating all of these technologies into various fields of industry. This idea is predicted to be the next industrial revolution. The number four in the term industry 4.0 refers to the fourth revolution. Industry 4.0 is a unique phenomenon compared to the three industrial revolutions that preceded it. Industry 4.0 was announced a priori because real events had not yet taken place and were still in the form of ideas (Drath and Horch, 2014).

The term industry 4.0 itself was officially born in Germany precisely when the Hannover Fair was held in 2011 (Kagermann et al, 2011). Germany has a big interest in this matter because industry 4.0 is part of its development plan policy called the High-Tech Strategy 2020. The policy aims to keep Germany in the forefront of manufacturing (Heng, 2014). Several other countries also participated in realizing the concept of industry 4.0 but using different terms such as smart factories, industrial internet of things, smart industry, or advanced manufacturing. Even though they have different terms, they all have the same goal, which is to increase the industrial competitiveness of each country in the face of a very dynamic global market. This condition is caused by the rapid development of digital technology utilization in various fields. Industry 4.0 is predicted to have a large one. Table 1 shows industry 4.0 according to several articles. Industry 4.0 does offer many benefits, but also has challenges that must be faced.

Miniard et al (1991) give the relationship between fake news, brands and advertising, it found out that the first and the essential driver that is behind the spread of fake news is the advertising, with the effects of digitalization that it becomes the head of the news industry, and that is leads to create the storm for brands and advertising. The way for such a thing s to spread very easy is that the digitalization makes everything goes fast, first form publishers to consumers to the consumers between them in the digital channels. The importance role of social media platforms in the user generated content, this study uses a content as the main objective to see how and the time it takes to spread in the social media in general, and it gives also parallel cascades similar to the main one, the diffusion of these can be inhibited or amplified with each other, the main social media used in this study is the Twitter data, as a results the content contributors of the small and individual social media should avoid publishing repetitive content, so they should do an effort to develop new content, but for the large content contributors are not concerned about this. (Yoo et al, 2019).

\section{Benefit Potential Industry 4.0}

The policy aims to keep Germany at the forefront of manufacturing in the world. Drath and Horch (2014) argue that the challenges faced by a country when implementing Industry 4.0 are the emergence of resistance to demographic changes and social aspects, instability in political conditions, limited resources, risks natural disasters and demands for the application of environmentally friendly technologies. According to Qin et al (2016), there is a wide gap in terms of technology between the current state of the industrial world and the conditions expected from industry 4.0. Research conducted by Balasingham (2016) also shows that there is a reluctance of companies to implement industry 4.0 because they are worried about the uncertainty of its benefits. Based on some of these explanations, according to what was conveyed by Zhou et al (2015), in general there are five major challenges that will be faced, namely aspects of knowledge, technology, economics, social, and politics. In order to answer these challenges, a large, planned and strategic effort is needed both from the regulator (government), academics and practitioners. Kagermann et al (2013) convey the 
need for academics' involvement in the form of research and development to realize industry 4.0. According to Qin et al (2016) the roadmap for developing technology to realize industry 4.0 is still not directed. This happens because industry 4.0 is still in the form of an idea whose actual form from all aspects is unclear so that it can bring up various possible directions for development.

German Chancellor Angela Merkel (2014) argues that industry 4.0 is a comprehensive transformation of all aspects of production in the industry through the merger of digital and internet technology with conventional industries. Schlechtendahl et al (2015) emphasize the definition of the speed element of information availability, which is an industrial environment in which all entities are always connected and able to share information with one another. A more technical understanding was conveyed by Kagermann et al (2013) that industry 4.0 is the integration of the Cyber Physical System (CPS) and the Internet of Things and Services (IoT and IoS) into industrial processes including manufacturing and logistics and other processes. CPS is a technology to combine the real world with the virtual world. This integration can be realized through integration between physical and computational processes (embedded computers and network technology) in a close loop (Lee, 2008). Hermann et al (2016) added that industry 4.0 is a term to refer to a set of technology and value chain organizations in the form of smart factories, CPS, IoT and IoS. Smart factory is a modular factory with CPS technology that monitors the physical processes of production and then displays it virtually and decentralizes decision making.

Through IoT, CPS is able to communicate with each other and work together in real time, including with humans. IoS are all service applications that can be utilized by every stakeholder both internally and between organizations. There are six industry 4.0 design principles namely interoperability, virtualization, decentralization, real time capabilities, service oriented and modular in nature. Based on the above explanations, industry 4.0 can be interpreted as an industrial era in which all entities in it can communicate with each other in real time at any time based on the use of internet technology and CPS in order to achieve the goal of achieving new value creations or optimizing existing values from every process in the industry. Technology never stops developing and often helps people meet their needs, both on a small and large scale. Technology makes it easy for humans to complete a job by saving time and energy, is no exception in the problem of shopping. As the times change, the habits of purchasing goods change from offline shopping to online shopping. Starting from small things like cellphones and internet quota, can be purchased online at e-commerce or refill through m-Banking, no need to walk to the credit counter. People who usually only buy shoes or clothes online, are now starting to buy household necessities such as brooms, mops, to vegetables on the internet. Online shopping is said to be more practical and cheaper.

The e-commerce business began in the 1990s, although at that time it was not yet widespread, referred to as the e-commerce 1.0 era where it was still in the form of a catalog of goods. E-commerce 2.0 is the period where the process of ordering and shipping goods, generally still using a website that can only be accessed using a computer. Continues to e-commerce 3.0 which is still common today, namely buying and selling activities carried out using mobile equipment. At this time, the business began to mushroom in various social media such as Instagram, Twitter, Facebook, and others. Humans began to develop ideas to continue to expand their business in accordance with technological advances. Now, e-commerce has reached e-commerce 4.0 phase which involves various technological developments such as Artificial Intelligence (AI) and internet of things (IoT). E-commerce 4.0 as part of the Industrial Revolution 4.0 is something that must be faced. There needs to be mastery of technology to be able to keep up with the flow of business development in this era. The convenience offered by technology is increasing so that potential buyers prefer to shop and use services just by opening the application on the device.

The effects that come with social media lately touch the brands and users both, with the digitalization, social media not only has impacts on communication but also self-expression that is used by individuals and organizations. This article observes the utilization of social media from brands, so it treats the way of marketing and branding how it is achieved by brands that use social media platforms.

First the brands know their target audiences in social media, and they have different goals of social media utilization, and as a result they develop solid brand identity (Angeline et al. 2019). The internet marketing is a new tool in the marketing of anything either a product or service, it is directed to the targeted market around the world. So, the electronic commerce is a part from the internet marketing, it is a need for the advertisers to be successful. For the marketing managers, it is a easy way and it relieves them from adding plans, it is a solution for an easy development of the company (Yazdanifard et al, 2011).

The industry 4.0 is a development in manufacturing system; it is not only for the technological era but also versatile organizational implications. The change from product to service orientation is predictive. The born of new types of companies that adopt new roles in the manufacturing process resp. the appearance of the industry is along with the analog types of companies, all with the changes in the financial services comparing with brokers and clearing points. With the development that it is happening in the information systems, a great task for the academic discipline of BISE arises will develop the competition between industrial enterprises (Lasi et al, 2014).

The trend lately is the modularization in purpose of maintaining mass production efficiency, with limitations to mass customization. In the design phase, the costumers are not participating; the designers are predetermined the potential combination, for the mass customization, its purpose nether to satisfy individual requirements nor providing personalized services and goods. Industry 4.0 is a concept of chain organization and technologies terms, based on radio frequency concept, cyber physical system, the internet of things, service internet, and data mining, it is a new form of personalization. The customers are enable to input design for companies to 
customized products with short time and less price than the companies who are doing the standardization, so that the producer and customers are both in hands to create new value, it is the purpose of filling the gaps between mass customization and mass personalization, all it can be with the usage of industry 4.0 (Wang et al, 2017).

According to Kotler \& Armstrong (2012) e-commerce is an online channel that can be reached by someone through a computer, which is used by business people in carrying out their business activities and is used by consumers to obtain information using computer aids which in the process begins by providing information services to consumers in determining selection. According to Wong (2010) e-commerce is the process of buying and selling and marketing goods and services through electronic systems, such as radio, television and computer networks or the internet. So it can be concluded that e-commerce is a dynamic collection of technology, applications and business processes that connect companies and consumers and certain communities where the exchange of goods between retailers and consumers of various commodities in a large scale and an electronic transaction, and in the process of sending goods from retailers use transportation from one region to another until it reaches the consumer and the relationship is a mutually beneficial relationship between the two parties. Here are four types of e-commerce based on their characteristics according to Kotler (2012):

\section{Business to Business (B2B)}

i. Business partners who already know each other and have established long-standing business relationships.

ii. Data exchange that has been going on is repeated and has been mutually agreed upon.

iii. The commonly used model is peer to peer, where processing intelligence can be distributed by both business people.

\section{Business to Consumer (B2C)}

i. Open to the public where information can be disseminated to the public as well.

ii. The service used is also public so it can be used by many people.

iii. Services are used on request, so producers must be able to respond well to consumer demand.

iv. The system approach is client-server.

Consumer to Consumer ( $\mathrm{C} 2 \mathrm{C})$ that is, a business model where the website is not only helping to promote merchandise, but also provides 20 on line money transaction facilities. In this case there are 2 (two) main indicators for a marketplace website: (i) all online transactions must be facilitated by the website concerned, (ii) can be used by individual sellers.

Consumer to Business (C2B): In contrast to business to consumer (B2C), in consumer to business, consumers (individuals) act as value creators where companies that will become consumers are carried out electronically.

Michael J.Shaw (2000) explains that the very broad spectrum of processes of existing buying and selling transactions, it is very difficult to determine the scope or boundaries of the e-commerce domain. One way that can be used to understand the limitations of an e-commerce is to try to examine and see the business phenomenon from various dimensions, namely;

i. Technology is the biggest contributor that makes e-commerce possible is information technology, in this case the rapid development of computer and telecommunications technology. It is undeniable that the area of buying and selling in cyberspace was formed because of the connection of millions of computers to an internet network. From this point of view e-commerce can be seen as a procedure or mechanism of buying and selling on the internet where buyers and sellers are brought together in a virtual world consisting of many computers.

ii. In terms of marketing e-commerce is often seen as a channel or a new way to connect with customers. Through e-commerce the reach of a company is becoming wider because the relevant parties can market their products and services throughoutthe world without regard to geographical boundaries. In the same way, a company can deal directly with its customers.

iii. Economic e-commerce is a trigger for the formation of new economic principles better known as the digital economy. In this economic concept, all resources that can be digitized are unlimited and have the potential to become public goods that can be freely owned by anyone. In this economic concept information and knowledge are also the determining resources for the success of economic actors in carrying out their activities.

iv. Electronic linkage is very important. On the other hand, many people see e-commerce as a mechanism of electronic relations between one another. With e-commerce, the two divisions can work together efficiently through electronic data exchange; likewise, between two different groups such as for example between customers and certain companies.

v. Information is value adding in e-commerce, the most important raw material is information. In this connection, the process of value added is the key to the implementation of an E-Commerce mechanism. This concept is strengthened by the theory of virtual value chains that illustrates how the value-added process is applied to information.

vi. Market making e-commerce is said to be market making because its existence has directly formed a separate trading market that brings together millions of sellers and buyers in a virtual digital market (e-market). In this virtual market trading is open and free, because each seller and buyer can meet efficiently without intermediaries.

vii. Service infrastructure is the concept of e-commerce did not produce a mechanism of buying and selling transactions, but it turned out that a lot of new services were needed as a means of supporting the sale and purchase of these products. Say services from financial institutions to offer ways to conduct transactions securely, services from Internet Service Provider 
(ISP) that offer ways to access the internet quickly and cheaply, hosting company services that offer data storage devices or the company's website in question.

E-commerce public policy tries to see in terms of laws, regulations, policies, processes, and procedures that apply. Indirectly, it can be seen that the electronic commerce contractions which have eroded the boundaries of space and time make it a new challenge for the government and society in trying to make certain regulations.

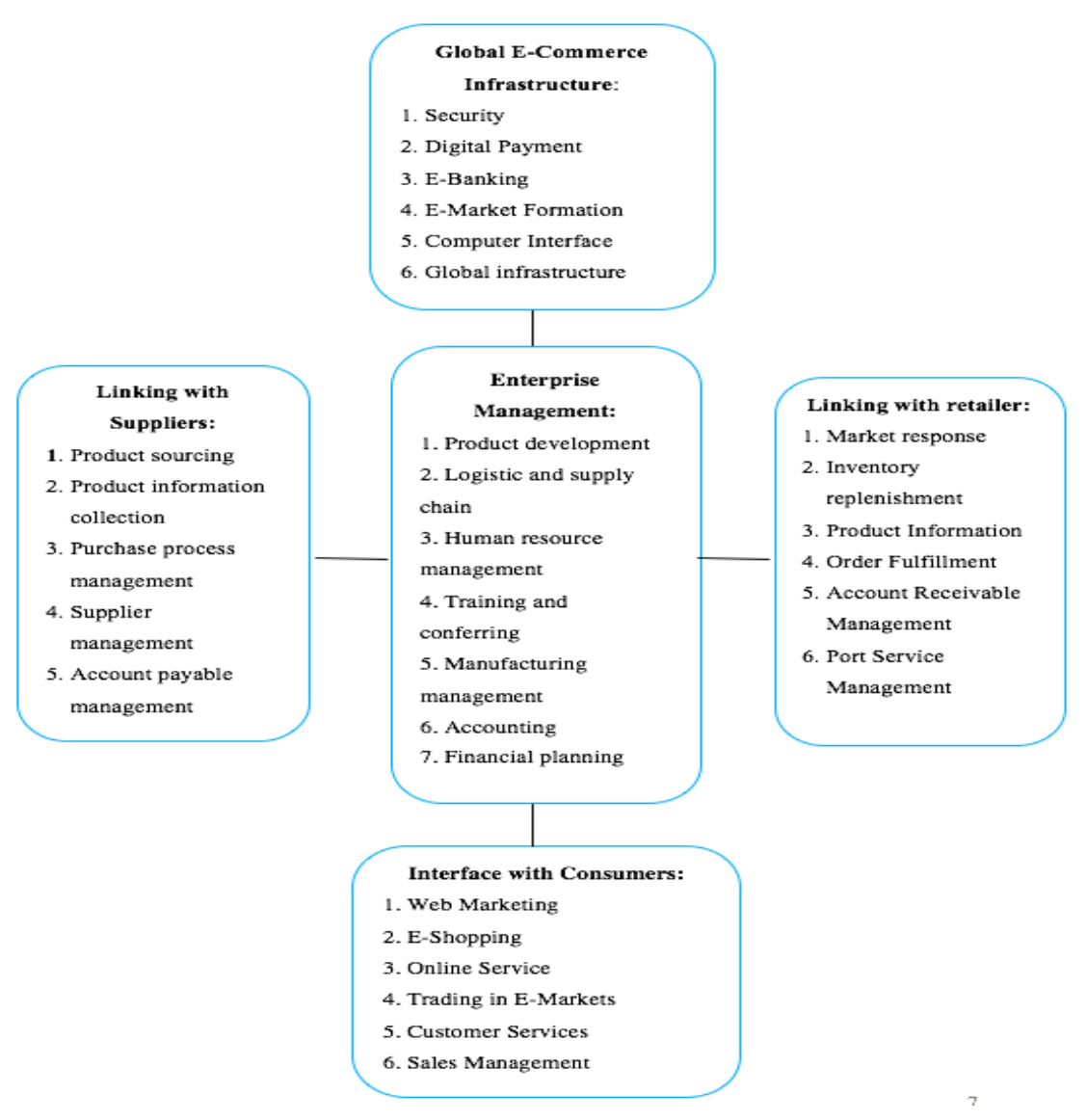

Fig. 1: Scope of E-Commerce; Source: Michael J.Shaw, 2000; Indrajit, 2002:73

Based on these eight perspectives, Shaw (2000) concludes five domains that limit the scope of E-Commerce, namely each as a means to:

i. Enterprise management connecting divisions within the company by flowing information from one place to another through digital media.

ii. Linking with suppliers linking a company with one or all of its business partners electronically so that the ordering and procurement of raw materials for production can be carried out as efficiently as possible.

iii. Linking with retailers connect with distributors, wholesalers, and retailers who are responsible for distributing products from the company into the hands of customers.

iv. Interface with consumers connect companies with prospective buyers directly without going through an intermediary.

v. Global e-commerce infrastructure connecting companies with other supporting parties such as vendors, ISPs, financial institutions, infrastructure service providers. The party is a supporting institution in order to carry out a complete series of e-commerce transaction processes. 


\section{E-Commerce Marketing Strategies in Industry 4.0}

In the industry 4.0 which has a variety of theories and models to achieve the goals of a business. Below is a draft of 9 stages of ecommerce strategy to improve marketing that can compete in the industry 4.0.

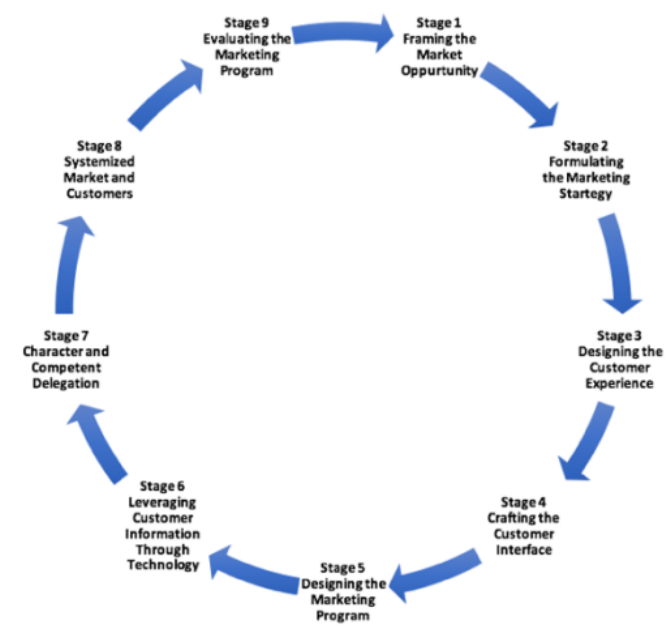

Fig. 2: Nine Marketing Strategy in Industry 4.0; Source: Marketing Strategies Analysis

Developing 7 internet marketing cycle theories from Mohammed (2003), the author develop and discover 9 internet marketing steps that should be done by e-commerce actors in the industry 4.0 era, including:

\section{Framing the Market Opportunity}

The first stage in internet marketing shapes market opportunities and collects data from online and offline systems to create opportunity assessments. At this stage, there are 6 parts of a simple methodology for evaluating and shaping market opportunities, including in the following table.

Table 1: Transitioning Firms Identified under the Manufacturing Industry

\begin{tabular}{|c|c|}
\hline Opportunity Analysis steps & Benefit of Step \\
\hline $\begin{array}{l}\text { Investigate Opportunity in an } \\
\text { Existing of New Value System }\end{array}$ & $\begin{array}{l}\text { This section is used to broadly identify which areas will be entered by new companies and what } \\
\text { opportunities can be obtained to enable companies to enter the market. }\end{array}$ \\
\hline $\begin{array}{l}\text { Identify Unmet or Underserve } \\
\text { Customer Needs }\end{array}$ & $\begin{array}{l}\text { The creation of new value is based on doing a good job of seeing what is needed by the customer by } \\
\text { identifying business processes in the existing company to see whether the current system can meet customer } \\
\text { needs or not. The key activity at this stage is to identify one of the unmet needs or needs that have been met } \\
\text { but in a better way. }\end{array}$ \\
\hline $\begin{array}{lll}\text { Determine } & \text { Target } & \text { Customer } \\
\text { Segments } & & \end{array}$ & $\begin{array}{l}\text { Segmentation is the process of grouping customers based on the similarities that exist in them. After } \\
\text { grouping customers into different segments, the company must determine the target segment of the } \\
\text { company. Some customer grouping approaches, Geographic; country, area, city, or ISP domain. } \\
\text { Demographic; age, gender, occupation, ethnicity, income, family status, standard of living, internet } \\
\text { connectivity and browser type. Firmographic; differentiate markets based on companies. Behavioral; online } \\
\text { or offline shopping behavior, website usage, etc. Occasion; time, location, event, special event and others. } \\
\text { Psychographic; lifestyle, personality, and affinity. Benefit; trust and attitude or behavior. }\end{array}$ \\
\hline Requirement to Deliver Offer-ing & $\begin{array}{l}\text { At this stage, the company must identify the resources that can be offered to customers as well as the } \\
\text { technology needed to meet the needs of the customers. Resources from the company itself include customer } \\
\text { facing resources, internal and upstream. }\end{array}$ \\
\hline $\begin{array}{l}\text { Assess Competitive, Techno-logy } \\
\text { and Financial Attractive-ness of } \\
\text { Opportunity }\end{array}$ & $\begin{array}{l}\text { Factors that companies can use to assess opportunities include competitive intensity, customer dynamics, } \\
\text { technology vulnerability and microeconomics. }\end{array}$ \\
\hline Conduct Go / No-Go Assessment & $\begin{array}{l}\text { At this stage, discussed the final decision making based on every opportunity that has been successfully } \\
\text { analyzed by the company. Where the opportunity will be used as a measure of whether Go / No-Go for } \\
\text { companies to be able to do e-marketing. In determining Go / No-Go, there are three parameters of } \\
\text { measurement namely positive factors, neutral factors and negative factors. }\end{array}$ \\
\hline
\end{tabular}

Source: Marketing Strategies Analysis 


\section{Formulating the Marketing Strategy}

In the previous stage the Go/No-Go decision was taken, then the next step was to determine an online marketing strategy. This stage includes four main components, namely:

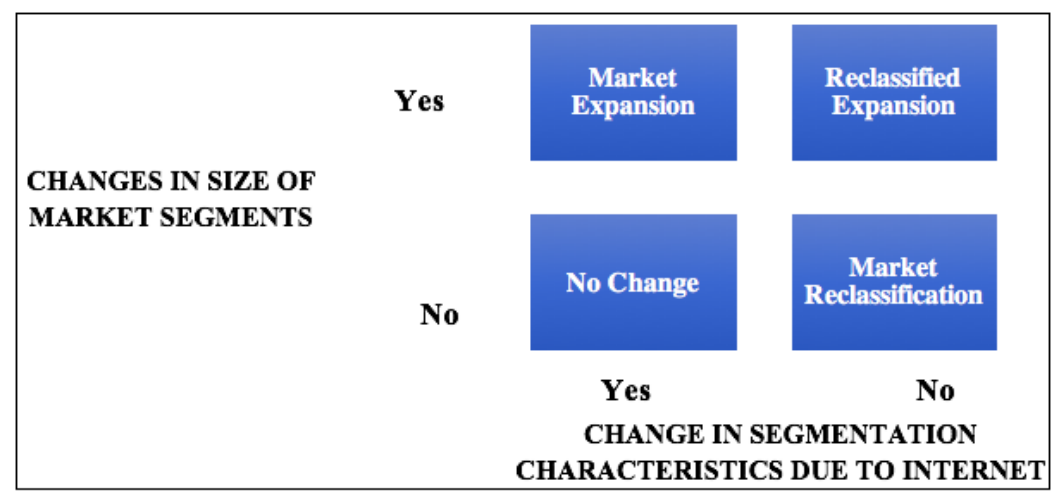

Fig. 3: Segmentation Scenario: Source: Marketing Strategies Analysis

\section{Segmentation}

Identify market segments and determine which targets to target by the company based on certain factors. Within the Bricks and Mortars for segmentation there are four possibilities, namely:

i. No Change: It is possible that after online marketing it is still the same as offline marketing and does not show significant new segments, and the size of online market segmentation remains the same as in offline market segmentation.

ii. Market Expansion: It is possible that after the implementation of online marketing, the characteristics of online customer segmentation are still the same as offline, but the size of market segmentation is changing.

iii. Market Reclassification: It is possible that after applying online, the characteristics of customer segmentation will change from offline marketing, but the size of market segmentation does not experience a significant change from offline marketing.

iv. Reclassified Expansion: It is possible that after the implementation of online marketing, the characteristics of customers and the size of segmentation both experience significant changes from offline marketing.

\section{Targeting}

In determining customer segmentation targets, there are four different scenarios which are described as follows:

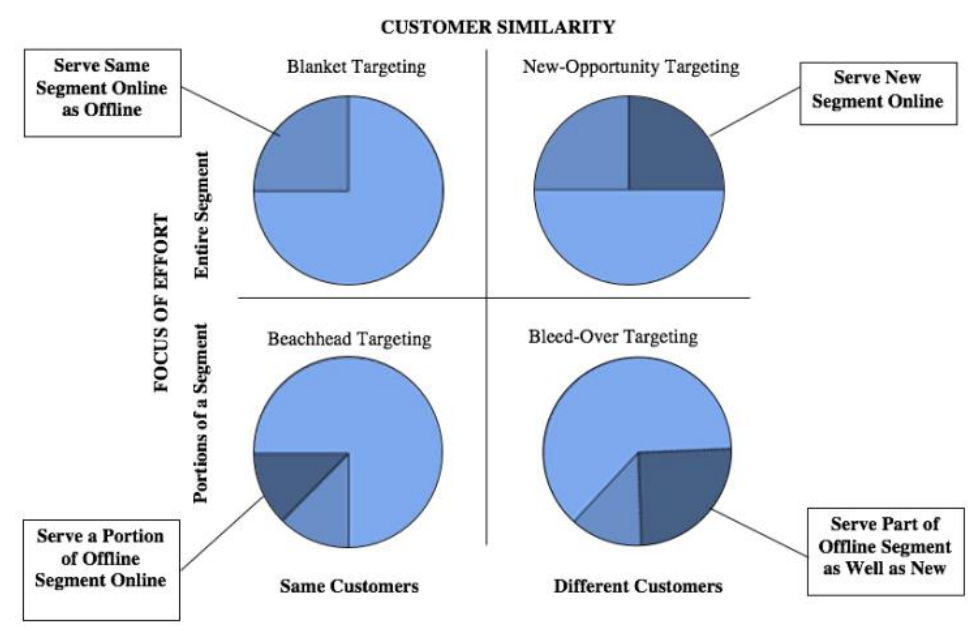

Fig. 4: Targeting Scenario; Source: Marketing Strategies Analysis 
i. Blanked Targeting: The characteristics of online marketing segmentation have not changed from offline, but the segmentation is expanding as geographical reach increases.

ii. Beachhead Targeting: Online segmentation is smaller than offline segmentation, which might represent a more focused taste or taste group. This might happen, if only a portion of customers access the internet.

iii. Bleed Over Targeting: Online segmentation targets include a portion of offline segmentation, as well as inserting new segmentations that did not exist before in offline. Targeted segments include individuals who were previously ignored in offline, but are targeted because the online system offers what is attractive to these customers.

iv. New Opportunity Targeting: Online segmentation targets are completely different from target segmentation when companies run offline marketing. If this type of targeting is chosen, usually the company must have a completely different brand from offline.

\section{Positioning}

The positioning approach scenario based on the choice of targeting scenarios is divided into four, namely:

\begin{tabular}{|c|c|c|}
\hline \multirow{3}{*}{ 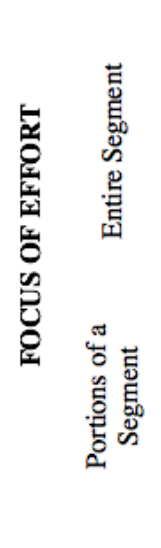 } & $\begin{array}{l}\text { - Blanket Targeting } \\
\text { - Borrow heavily from existing } \\
\text { offline positioning } \\
\text {-Tout basic advantages of the } \\
\text { Internet-convenience and } \\
\text { accessibility }\end{array}$ & $\begin{array}{l}\quad \text { Bleed-Over Targeting } \\
\text { - Use dual positioning } \\
\text {-Leverage existing } \\
\text { positioning } \\
\text { •Position added benefits, such } \\
\text { as augmented offerings via } \\
\text { the internet (e.g. Increased } \\
\text { product customizability) }\end{array}$ \\
\hline & $\begin{array}{l}\quad \text { Beachhead Targeting } \\
\text { - Also borrow from offline } \\
\text { positioning } \\
\text {-Focus more, however, on } \\
\text { needs of the smaller group } \\
\text {-Stress value-added advantages } \\
\text { of the Internet }\end{array}$ & $\begin{array}{l}\text { New Opportunity Targeting } \\
\text { - Reposition entirely } \\
\text {-Position differentiations } \\
\text { which cater to the new } \\
\text { segment }\end{array}$ \\
\hline & Same Customers & Different Customers \\
\hline
\end{tabular}

Fig. 5: Positioning Scenario; Source: Marketing Strategies Analysis

\section{Designing the Customer Opportunity}

At this stage, we will try to design the experiences that we expect our customers to get from the company. There are three stages in building a customer experience, namely:

Functionality: These are the factors that determine whether a site that is created will work well or not. Five factors of functionality, namely

i. Usability and Ease of Navigation: Measured by how well a website anticipates user needs that are influenced by various elements, including load speed, page structure, and graphic design.

ii. Speed refers to the time taken to display a web page on the user's screen.

iii. Reliability describes the level at which a website experiences a downtime period, or the time when a user cannot get access to the website because of maintenance.

iv. Security by which customers want to know they can trust a particular website, when security and comfort is combined, the customer experience is improved.

v. Media Accessibility is the ability of a website to retrieve data on various media platforms.

Intimacy: At this stage, customers feel that the company has a very good understanding of their needs and desires which are generally manifested in various customization for the appearance of the website the customer wants. The customer is obtained as are Customization, Communication, Clearly, Consistency, Trustworthiness, Exceptional value, Shift consumption to leisure activity

\section{Crafting the Customer Interface}

In designing a good interface, the "7C" framework is used to identify the main display design encountered when implementing a business model. These elements, i.e.:

Context: A web page must be able to capture aesthetics and function can see and feel. The main focus is on attractive graphical displays, colors and design aspects, while others have emphasized objectives that can be useful such as making navigation. Three critical factors in the appearance of a site are section breakdown/subcomponent, linking structure and navigation tools. 
Content: The contents can be confirmed with all things that are digital in a website. Media used are text, video, audio, and images or graphics that can convey messages clearly, including products, services and information provision. The four main dimensions in content are offering mix, appeal mix, multimedia mix and content type.

Community: Relationships are built based on the same interest in something, both between customers and companies and customers with customers can attract customers to return to visit the website again.

Customization:The ability of a website to be modified both by the company and by each customer.

Communication: Dialogue involving the website and its users. This communication can occur in three forms, namely; Company to customers (e-mail); Customers to the company (customer service); and Customer to customer (instant message).

Connection: Network that connects one site to another.

Commerce: The ability of the website to conduct sales transactions of goods, products or services, namely by shopping charts, shipping and payment options, checking and order confirmation.

\section{Designing the Marketing Program}

At this stage, it is a marketing program design that is used to combine marketing strategies in a combination and can move the target customer from each stage of awareness about the company's products to the commitment stage and ends at the dissolution stage. There are four customer relationships, i.e.:

i. Awareness: The stage where the customer has basic knowledge or views of the company or products offered by the company but has not yet started communication with the company.

ii. Exploration/Expansion: The stage where the customer starts communicating and actions that are likely to continue towards a closer relationship, where the customer starts to be interested in exploring the company's website and looking for information in it.

iii. Commitment: This stage involves having responsibility for the product or company. Customers will periodically access the website and provide views and attitudes that reflect loyalty.

iv. Dissolution: This stage occurs when one or both parties (the company and the customer) break the relationship. The internet marketing mix consists of six classes of levers, which are product, pricing, communication, community, distribution and branding.

The Marketspace matrix is a tool used to design a combination of marketing mix activities to move customers from the awareness stage to the commitment stage.

\begin{tabular}{|c|c|c|l|l|l|}
\hline \multirow{4}{*}{\begin{tabular}{c} 
CATEGORIES \\
\cline { 2 - 6 } OF LEVERS
\end{tabular}} & Product & & & & \\
\cline { 2 - 6 } & Price & & & & \\
\cline { 2 - 6 } & Communication & & & & \\
\cline { 2 - 6 } & Community & & & & \\
\hline & Distribution & & & & \\
\hline
\end{tabular}

Fig. 6: Market Space Matrix; Source: Marketing Strategies Analysis

\section{Leveraging Customer Information Through Technology}

Companies can use technology assistance to get, analyze, and utilize information about customers so that companies will better understand and know customers to know what customers need. This can be done through:

i. Marketing Research: A tool that helps companies to understand and fulfill the desires and wishes of customers, which can provide information about the quality and usability of the products and services that customers need.

ii. Database Marketing: A tool consisting of customer information acquisition. Analyzing this information is useful for estimating customer responses to certain offers, and making marketing decisions based on expected responses.

iii. Customer Relationship Management: A tool that establishes long-term profitability of customers and maintains key customers. Customer information is a strength and customer information systems can make companies increase strength.

\section{Character and Competent Delegation}

E-commerce doer in the industry 4.0 who are in a position of authority know that relinquishing control and delegating tasks to others is not easy. Delegating tasks is one of the best ways to optimize productivity, manage large workloads, and aim to achieve goals on time. There are 5 delegation techniques that can be carried out by an e-commerce company leader in the industry 4.0, including: 


\section{Give Duty and Trust completely}

In order to successfully delegate tasks, the leader of the e-commerce company must take the big risk of relinquishing control to employees. Stop thinking that only e-commerce company leaders have good ideas and give team members confidence. Delegating tasks does not mean making decisions for team members. Give employees space to develop critical thinking skills, so they can produce the best ideas and solutions. Delegate tasks by releasing light tasks to employees. When they are able to do the job well, then give the job a higher priority than before. By using the approach above gradually, e-commerce company leaders can improve employee competencies and increase their confidence in accordance with the challenges in industry 4.0.

\section{Delegate Tasks to the Right Person}

When you are going to delegate a task, consider a definite decision. It is not permissible to delegate tasks to the wrong person. Observe the person given the task, regarding strengths, weaknesses, and skills possessed by team members. Knowing this, makes it easy for e-commerce company leaders to adjust tasks to the right people with the work to be given.

\section{Convey Instructions Clearly}

Not being able to deliver instructions correctly will affect the failure of the job or job done by the employee. In order to increase the chances of a job being done well, e-commerce company leaders must provide clear instructions to employees. Cannot confuse the instruction given. As an initial step e-commerce company leader can provide guidance to employees to perform tasks, if they can do it right, then e-commerce company leaders relinquish control for them.

\section{Delegate Jobs Based on Interests and Interests}

Interest and interest in something is one reason you can use to motivate employees to do what is their job. In addition to adjusting skills to the tasks to be given, e-commerce company leaders must be able to encourage team members to perform tasks that interest them. The leader of the e-commerce company builds the reasons for what makes employees willing to perform the assigned tasks or work that motivates them to compete in the industry 4.0.

\section{Set Deadlines and Evaluate}

When e-commerce company leaders delegate tasks to employees, be sure to deliver when the deadline for the work must be completed. The leader of the e-commerce company must conduct an evaluation of the work and tasks so that the desired target runs in accordance with the objectives. Schedule job evaluations once a week and e-commerce company leaders can check the results of the work after they have carried out half of the tasks assigned. The main goal is to ensure that every delegated work runs properly and that there are no deviations done by employees. Concern with the work and tasks that have been given to employees, will increase employee respect to e-commerce company leaders.

\section{Creating a Systematic Market and Customers}

Provide good service to customers. The key to making perfect customer service is to exceed customer expectations, not just meet customer expectations. Give customers repeat orders because of the service the company gives. Listening to customers is an effective way to find out customer needs, by finding these companies will know the needs of customers with certain products and servants that must be applied in the industry 4.0. Describe the needs in detail, to meet extensive customer service by providing recruitment and training to employees so that they can provide good service to customers. Using supporting technology, in industry Era 4.0 as the leader of an e-commerce company, it is best to facilitate employees with internal database access called Customer Loyalty Anticipation Satisfaction System (CLASS) which stores customer information in the past collected by the company so employees can offer service which is satisfactory based on a database that is already owned in the industry 4.0. To be more professional in determining the market in the industry 4.0, e-commerce businesses must have a systematic market to support business growth. In a systematic market, a company can develop product positions and marketing strategies for each type of market that are beneficial for make it easy to adjust the product, marketing mix strategy and develop product positions. Identify the parts of the market that can be effectively served, the company can be in a better position.

a. Anticipating competition.

b. Make use of limited company resources efficiently and effectively.

c. Target broader market opportunities.

d. Place marketing ideas more clearly.

e. Manage products better.

f. Find and compare market opportunities.

g. Classifying the budget that is owned appropriately.

h. Creating attraction in the marketing field.

i. The company will be in a better position.

In the industry 4.0 to create a systematic, successful market, e-commerce entrepreneurs must pay attention to factors related to the systematic market as follows: 


\section{Segment Size}

Large e-commerce companies tend to choose large market segments and vice versa, small e-commerce companies will choose smaller market segments. It is intended that companies can adjust company targets according to their individual abilities.

\section{Segment Growth}

Segment growth factor is also one factor that must be considered in determining a more systematic market.

Situation Analysis

Perform a careful and careful situation analysis before determining a system of markets. The analysis of the situation relates to consumers, suppliers, and distributors using SWOT (Strengths, Weaknesses, Opportunities, Threats) analysis.

\section{Company Resources}

Before determining the target market, try to pay attention to the resources obtained by the company. If the company's resources are obtained from cooperation with outside parties.

\section{Costs that must be spent to reach the segment}

A segment must be adjusted to the company's marketing activities, if the selected segment is not suitable then it should not need to be done. Therefore, identification of the segment to be addressed must be done carefully. Many examples of segments that were estimated to have great potential, but not as expected, while the company has incurred large costs.

\section{Suitability of Purpose}

After the market segment is determined, the company should continue to focus on that segment. As much as possible the company should not switch to other market segments that were not previously planned, because the risk of loss is quite large.

\section{Target Market Implementation}

After the market segmentation process is carried out, the next step is the implementation of the target market. To do this, an orderly and systematic process is needed, which are develop marketing references to determine targeted market segments, select market segments and target companies, develop products that fit market segments, develop a profile of the market segment that will be generated, add market segment criteria if needed an identify existing market segments.

\section{Evaluating Marketing Program}

This last stage evaluates all marketing programs whether they reach the goal. Use parameters to measure the success of an online marketing program and whether it matches the objectives of the company. In this stage, the Marketing Metrics Framework consists of:

i. $\quad$ Financial Metric is used to measure basic results and is the overall level.

ii. Customer Based Metrics is used to see marketing performance in building customer-oriented assets that will be generated financially.

iii. Implementation Metrics is used to see how effective and good the performance of the elements in marketing programs in terms of building customer oriented asset.

\section{Conclusion}

This study evaluates the development of e-commerce in the industry 4.0 and it rapidly has a positive impact both for business people, consumers and society. For business people, e-commerce has a positive impact in the form of reduced operational costs and can widen market share, so that profits can be maximized and easier in terms of business development. The development of e-commerce is strongly influenced by the level of regional development. In the industry 4.0 to achieve the goals of a business with challenges and high competitiveness in the e-commerce market, business people can use 9 marketing strategies to achieve this, including; framing the market opportunity; formulating the marketing strategy; designing the customer experience; crafting the customer interface; designing the marketing program; leveraging customer information through technology; character and competent delegation; systemized market customers; and evaluating the marketing program. The development of e-commerce continues to grow in the industry 4.0, demanding that e-commerce business players be more active and must update information on the development of the digital business world that is constantly changing vertically in order to continue to compete with other e-commerce businesses. Human development is a very important aspect in the development of e-commerce because in conducting e-commerce activities requires technology which in its mastery requires high knowledge. After adequate human resources, network infrastructure also determines the development of e-commerce in a region. E-commerce entrepreneurs need to implement marketing strategies to build and increase the trust of internet users, both consumers and potential consumers by taking into account the determinants of trust such as maintaining reputation by providing reliable services, maintaining customer satisfaction, showing professionalism, making it easy to transact, giving clear instructions, and guarantee product. 


\section{Acknowledgements}

This study is dedicated to our supervisor Professor Umit Hacioglu at Ibn Haldun University.

\section{References}

Angeline, Mia., Chandra, Stephany., Kinanti, Farhana., Singgih, Yasa., and Safitri, Yuanita. (2019). Digitalize Your Brand: Case Study on How Brands Utilize Social Media Platforms to Achieve Branding and Marketing Goals. International Conference on Information Management and Technology (ICIMTech), 278-283.

Balasingham, K. (2016). Industry 4.0: Securing the Future for German Manufacturing Companies. Master'sThesis. University of Twenty.https://essay.utwente.nl/70665/1/Balasingham_BA_MA.pdf

Davies, R. (2015). Industry 4.0 Digitalization for Productivity and Growth. European Parliament Think Tank.

Drath, R., \& Horch, A. (2014). Industry 4.0: Hit or hype? (Industry Forum). IEEE Industrial Electronics Magazine, 8(2), pp. 56-58.

Heng, S. (2014). Industry 4.0: Upgrading of Germany's Industrial Capabilities on the Horizon.https://ssrn.com/abstract=2656608, (accessed 10 December 2019).

Hermann, M., Pentek, T., \& Otto, B. (2016). Design Principles for Industry 4.0 Scenarios. System Sciences (HICSS). 49th Hawai International Conference, pp. 3928-3937.

Indrajit, E. R., (2002). Concept and Application. Andi Publisher, Yogyakarta.

Jony Wong. 2010. Internet Marketing for Beginners. PT Elex Media Komputindo. Jakarta.

Kagermann, H., Lukas, W.D., \&Wahlster, W. (2011). Industrie 4.0: Mitdem Internet der Dinge auf demWegzur 4.0 industriellen Revolution.http://www.vdi-nachrichten.com/Technik-Gesellschaft/Industrie-40-Mit-Internet-Dinge-Weg-4industriellenRevolution. (accessed 1 December 2019.)

Kagermann, H., Lukas, W.D., \& Wahlster, W. (2013). Final Report: Recommendations for Implementing the Strategic Initiative Industry 4.0. Industry 4.0 Working Group.

Kotler, P., and Keller, K.L. (2012). Marketing Management 14th Edition. Upper Saddle River, N.J.: Pearson Prentice Hall.

Lasi, H., Fettke, P., Kemper, H. G., Feld, T., \& Hoffmann, M. (2014). Industry 4.0. Bus Inf Syst Eng 6 (4): $239-242$. https://doi.org/10.1007/s12599-014-0334-4.

Lee, E. A. (2008). Cyber Physical Systems: Design challenges. In Object Oriented Real-Time Distributed Computing (ISORC), 11th IEEE International Symposium, pp. 363-369.

McLaren, B.., and McLaren, Co. H. (2002). E-Commerce Basics, Second Edition (BASICS Series) 2nd Edition. Cengage Learning.

Merkel, A. (2014). Speech by Federal Chancellor Angela Merkel to the OECD Conference. https://www.bundesregierung.de/Content/EN/Reden/2014/2014-02-19-oecdmerkelparis_en. html. (Accessed 6 December 2019).

Mohammed, R. A. (2003). Internet Marketing: Building Advantage in a Networked Economy 2th Edition. Prentice hall.

Qin, J., Liu, Y., \& Grosvenor, R. (2016). A Categorical Framework of Manufacturing for Industry 4.0 and Beyond. Procedia CIRP, 52, 173-178.

Yazdanifard, R., Venpin, M., Yusoff, W. F. W., \& Islam, M. R. (2011). Internet marketing: The new era of innovation in e-commerce. In International Conference on Software and Computer Applications, 9, 192-197.

Schlechtendahl, J., Keinert, M., Kretschmer, F., Lechler, A., \& Verl, A. (2015). Making existing production systems Industry 4.0ready. Production Engineering, 9(1), 143-148.

Social, W.A. (2019). Digital 2019: Global Internet Use Accelerate. https://wearesocial.com/blog/2019/01/digital-2019-globalinternet-use-accelerates. (Accessed 8 December 2019).

Shaw, M. J. (2000). Web-based e-catalog systems in B2B procurement. Communications of the ACM. https://doi.org/10.1145/332833.332845.

Miniard, P. W., Bhatla, S., Lord, K. R., Dickson, P. R., \& Unnava, H. R. (1991). Picture-based persuasion processes and the moderating role of involvement. Journal of consumer research, 18(1), 92-107. https://doi.org/10.1086/209244.

Y. Wang., H.Ma., J. Yang., K. Wang. (2017). Industry 4.0: a way from mass customization to mass personalization production. Adv. Manuf. 5, 311-320 (2017). https://doi.org/10.1007/s40436-017-0204-7.

Yoo, E., Rand, W., Eftekhar, M., \& Rabinovich, E. (2016). Evaluating information diffusion speed and its determinants in social media networks during humanitarian crises. Journal of Operations Management, 45, 123-133.. https://doi.org/10.1016/j.jom.2016.05.007.

Zhou, K., Taigang L., \&Lifeng, Z. (2015). Industry 4.0: Towards Future Industrial Opportunities and Challenges. In Fuzzy Systems and Knowledge Discovery (FSKD), IEEE 12th International Conference, 2147-2152. 